\title{
MICRO-SIMULATION OF \\ SOCIAL SECURITY REFORMS IN BELGIUM
}

\author{
Rapheal Desmet \\ Alain Jousten \\ SergioPerelman \\ Pierre Pestieau \\ Working Paper 9494 \\ http://www.nber.org/papers/w9494
NATIONAL BUREAU OF ECONOMIC RESEARCH
1050 Massachusetts Avenue
Cambridge, MA 02138
February 2003

Financial support from FRFC (2.4544.01) is gratefully acknowledged. All remaining errors are entirely our own. The views expressed herein are those of the authors and not necessarily those of the National Bureau of Economic Research.

C2003 by Rapheal Desmet, Alain Jousten, Sergio Perelman, and Pierre Pestieau. All rights reserved. Short sections of text not to exceed two paragraphs, may be quoted without explicit permission provided that full credit including notice, is given to the source. 
Micro-Simulation of Social Security Reforms in Belgium

Rapheal Desmet, Alain Jousten, Sergio Perelman, and Pierre Pestieau

NBER Working Paper No. 9494

February 2003

JEL No. I3, R0

\section{$\underline{\text { ABSTRACT }}$}

The present paper analyzes the budgetary impact of various Social Security reforms in the Belgian institutional setting. Our approach relies on parameters that were derived in Dellis et alii (2002) using a micro-modeling strategy. focusing our attention on a hypothetical age cohort, we illustrate the budgetary impact that the reforms considered might have on the budget of the federal government.

Raphael Desmet

University of Liège, CREPP

Pierre Pestieau

Department of Economics

University of Liege

CESifo and CEPR
Alain Jousten

Department of Economics

University of Liège

ajousten@ulg.ac.be

and CEPR
Sergio Perelman

Department of Economics

University of Liège, CREPP 


\title{
Micro-simulation of Social Security Reforms in Belgium
}

\author{
R. Desmet, A. Jousten, S. Perelman and P. Pestieau*
}

December 10, 2002

\begin{abstract}
The present paper analyzes the budgetary impact of various Social Security reforms in the Belgian institutional setting. Our approach relies on parameters that were derived in Dellis et alii (2002) using a micro-modeling strategy. Focusing our attention on a hypothetical age cohort, we illustrate the budgetary impact that the reforms considered might have on the budget of the federal government.
\end{abstract}

\section{Introduction}

The various Belgian social security schemes face an uncertain future. The general trend towards demographic aging all across the developed world and large parts of the developing world has not left Belgium unaffected. Demographic aging is the result of a combination of two trends. First, there has been a substantial decrease in fertility rates of women over the last few decades. Second, we have observed a strong increase in life expectancy across most categories in the population. Unfortunately, these trends have a strongly negative financial impact on a variety of social insurance and social protection programs, ranging from child support payments, over the health care sector to the questions of retirement income and longterm care arrangements. While the problem can be approached in a myriad of ways, we approach the problem from the perspective of the social security system, thus largely leaving aside the question of health and long-term care costs. While it is true that this focus inhibits a truly global view of the financial consequences of aging for government budgets, it is also true that introducing it would cause tremendous problems in terms of modeling the evolution of health-care costs, as well as in terms of a loss of international comparability.

\footnotetext{
* Financial support from FRFC (2.4544.01) is gratefully acknowledged. All remaining errors are entirely our own. Comments welcomeat ajousten@ulg.ac.be. Raphael Desmet is researcher at the University of Liège, CREPP.

Alain Jousten is Professor of Economics at the University of Liège, Research Fellow at IZA and Research Associate at the CEPR.

Sergio Perelman is Professor of Labor Economics at the University of Liège and Research Director of CREPP.

Pierre Pestieau is Professor of Economics at the University of Liège, Research Fellow at CESifo and at the CEPR.
} 
For the social security systems to survive this demographic process, higher contribution levels and/or lower benefits will have to be introduced given the outright pay-as-you-go (PAYG) nature of these systems. Indeed, a straight increase in the public debt financing of the demographic transition is not truly an option in Belgium, as it would be totally incompatible with the Maastricht criterion of the European Economic Monetary Union (EMU) relating to the level of GDP.' But even beyond this purely institutional limit, a further increase in public debt levels is also financially unsustainable, as it would at short notice cause a snowball effect such as the one observed in Belgium in the 1980's.

Leaving aside these purely demographic considerations, other factors are challenging the way the Belgian social security institutions and systems are organized. First, there is the potential for increase labor mobility. At present, mobility between jobs in the public sector, the private sector and in self-employment is rather limited, at least partly because of the way the three systems work. The needs of the labor market of the future with its increased degree of flexibility may thus induce large changes in the way the three corresponding social security systems work. International job mobility is also becoming more and more important, particularly for a small open economy in the heart of Europe like Belgium. Jousten and Pestieau (2000) argue that both levels of intra- and intergenerational redistribution will be heavily affected by increased international labor mobility, even if the phenomenon is limited to some subgroups of the population.

The second and biggest non-demographic challenge is the widespread use of a variety of early retirement programs. In fact, Belgium excels in the use of these programs as the worldleading low average retirement age of approximately 57 for men clearly illustrates. ${ }^{2}$ Originally these systems were motivated by several objectives. Faced with an environment of industrial restructuring early retirement seemed to be the royal route out of the problem for all partners involved. First it allowed companies to lay off old workers and if needed hire cheaper young workers, while the government supported a large chunk of the costs. ${ }^{3}$ Older workers were also encouraged by the trade unions to leave to free up space for younger ones. To the present day, many older workers believe that they take a decision beneficial to their younger counterparts. Third, the successive governments since the 1970's were also political gainers, though financial losers, in this consensus towards early retirement because it allowed the government to show a better performance in terms of unemployment (particularly youth unemployment) and guaranteed a social peace. Lately however, these early retirement schemes have undergone some scrutiny. Not surprisingly, the beneficial labor market effects have been rather modest, if not completely absent. ${ }^{4}$ Recent discussions and decisions at the government level clearly move into the direction of lifting the effective early retirement age, and hence also the sector-specific mandatory retirement ages. Financial costs of early retirement programs to the federal government have been huge, both on the income (contributions, taxes) as on the expenditure side (early retirement benefits).

The goal of the paper is to simulate the impact of reforms of retirement income systems. The impact we are interested in resides on two levels. First, we consider the financial and behavioral impact on individuals and families. Second, we consider the financial impact on federal government budget. We do not restrict our attention to the budgetary impact on the social security systems, but rather on all of the federal government's finances. Such reforms will have both an automatic effect on fiscal contributions by changing contributions and

\footnotetext{
${ }^{1}$ Belgian national debt currently hovers at a level of approximately 110 percent of GDP.

2 The average age of retirement of 57,6 for men was estimated by Blöndal and Scarpetta (1998) on the basis of Labor Force Surveys. In this study we estimated an average retirement age of 58.4 for men and 57.4 for women.

3 Belgium is a country where the age profile of wages is steeply increasing with the length of the working career making older workers quite expensive.

${ }^{4}$ See Sneesens et al. (2002)
} 
benefits for a given work history (the "mechanical" effect) and an additional effect through labor supply responses to the reform (the "behavioral" effect). We will estimate the fiscal implications of both the mechanical and the behavioral effect, using our retirement probit models derived in Dellis et alii (2002) to predict labor supply responses. The result will be an estimate of the steady-state impact of the reforms on the financial balance sheet of retirement income systems.

The structure of the paper is as follows. Section 2 describes the essential features of the various public retirement and early retirement systems in Belgium. In section 3 we explain the different components of our administrative dataset, as well as the key results of Dellis et alii (2002) that we heavily rely upon. The following section describes the simulation methodology used. The approach can be qualified as being of a "steady-state" type. Our methodology implicitly assumes that there is a time-invariant social-security program and time-invariant behavior, though this has obviously not been the case for the systems and the people analyzed in our sample, where both behaviors and system characteristics have evolved over time. Section 5 describes the simulation results obtained. Again, it is important to stress that these results have to be interpreted with due diligence because of the limitations inherent in our simulation approach. Though the results might be rather accurate for the cohort of 50 year-old workers, this might not be the case for the more general population at other ages or for other cohorts. Section 6 is devoted to the conclusions.

\section{Social security schemes ${ }^{5}$}

The Belgian retirement income system relies on three very unequal pillars. First of all, there are the dominant public social security programs that represent the largest part of pension income for a wide majority in the population. A second pillar consists of company pension schemes, which only plays a minor role as a source of income for the average Belgian worker. Essentially, they are currently confined to the higher-income individuals in the private sector and to the self-employed, a finding which is at least in part due to their tax-treatment. A third type of retirement income comes from individual retirement savings. These take multiple forms: First, there are tax-favored individual pension savings accounts with a maximum annual contribution of EUR 580 per person ${ }^{6}$ or under the form of more traditional savings vehicles such as the tax-favored savings accounts, investments in trust funds, life insurance, etc.

The first pillar, public retirement programs, essentially consists of four components. There are three large sectoral social security programs, one for the public sector, one for the private sector wage earners and one for the self-employed. Some special categories of workers, such as coalmine workers and military personnel have special retirement systems that we will not explicitly model in the present paper. A fourth large category of public retirement income consists of the guaranteed minimum pension system, that operates on a means-tested basis.

\section{Wage-earner's scheme}

The wage earner's scheme is by far the largest one according to the number of people affiliated with the program. The program allows for retirement starting at age 60 , with a normal retirement age fixed at 65 . The choice of the retirement age does not induce any actuarial adjustment under current rules.

However, in the case of most workers, the choice of the retirement age is not completely neutral with respect to the benefit amount because a full earnings history consists of 45 years

\footnotetext{
${ }^{5}$ The present section heavily relies on Dellis et alii (2002).

${ }^{6}$ All financial data are presented in EUR of 31/12/2001.
} 
of work for men, a condition that many people do not satisfy at the age of 60 . For those having more than 45 working years, a dropout year provision operates replacing low-income years by higher ones. The situation has so far been slightly different for women who only needed 40 years to complete a career. A transition (between 1997 and 2009) is under way to progressively increase the complete career condition to 45 years of work. Hence, for most women included in our dataset, a full career still consists of 40 years of work. Additional years can be added to ones career by working, but also by spending additional time on other social insurance programs such as unemployment insurance, disability insurance, workers compensation or early retirement programs.

Benefits are computed based on the earnings during periods of affiliation. The benefit formula, which is subject to floors and ceilings, can be represented as follows:

Benefit $=\mathrm{n} / \mathrm{N} *$ average wage $* \mathrm{k}$

where $\mathrm{n}$ represents the number of years of affiliation with the wage-earner's scheme, $\mathrm{N}$ the number of years required for a full career (in our case either 40 or 45) and $\mathrm{k}$ is a replacement rate, which takes on the value of 0.6 and 0.75 depending on whether the social security recipient claims benefits as a single or as a household. The variable "average wage" corresponds to indexed average wages over the period of affiliation, with indexation on the price index combined with additional discretionary adjustments for the evolution of growth. A peculiar feature of the Belgian wage-earners scheme is that periods of the life spent on replacement income (unemployment benefits, disability benefits, workers compensation...) fully count as years worked in the computation of the average wage, and hence of the social security benefit. For any such periods, fictive wages are inserted into the average wage computation. In line with the general philosophy of the Belgian social insurance system that any such spell on a replacement income system is purely involuntary, imputed wages are set equal in real terms to those that the workers earned before entering these replacement income programs.

Wage-earners pensions are shielded against inflation through an automatic consumer price index (CPI) adjustment and are subject to an earnings test. Currently, the earnings limit is approximately EUR 7,450 per year. For earnings above this limit, pension entitlement is suspended. Benefits are also paid to surviving spouses, or more generally surviving dependents of deceased wage earners.

The wage-earners system is essentially based on the PAYG principle, and financed through payroll taxes that are levied both on the side of the employers and of the employees, with a combined tax rate of 16.36 percent (no earnings limit). The system also receives a subsidy from the Belgian federal government that is approximately equal to 11 percent of overall benefits.

Next to the official wage-earner scheme, several forms of early retirement programs have developed: mandatory collective retirement and individual early retirement. During the 1980's and the 1990's, an arsenal of mandatory early retirement schemes was put in place. All of these arrangements were and are based on collective agreements, which are negotiated with the active involvement of employees and employers, sometimes at the sector level, sometimes at the level of an individual company or production site. For some companies in a difficult economic position, mandatory retirement ages as low as 50 were introduced. Individual early retirement differentiates itself from its collective counterpart by the fact that it is based on an individual's decision to retire from work. During the years analyzed in our sample, the most prevalent way is to pass through the unemployment system in which unemployed aged fifty or more are considered 'aged unemployed' and no longer subject to show up at the unemployment office on a regular basis. Further, there is no control on availability to work, 
nor are there benefit cuts due to long-term unemployment. ${ }^{78}$ Therefore, people unwilling to continue to work can ask their employer to lay them off. Similarly, employers can use the system to shed older more expensive workers. The latter is often willing to do so because of a lack of experience rating in the unemployment insurance system. In the early years of the new millennium, a new technique has even reinforced the use of the unemployment insurance system as a retirement route. The technique, called "canadry dry" pensions, consists in a lump-sum transfer from the employer at the time the company lays off its worker. This lumpsum is formally not a retirement pension but clearly looks like one...

\section{Public sector employees}

Public sector pensions are paid out of the general federal budget and are officially considered as deferred income rather than old-age insurance. The only official insurance element is a coverage for survivor benefits, which is financed through a 7.5 percent payroll tax. No spousal benefits are available. Civil servants face compulsory retirement at the latest at age 65 for both men and women. However, as for the private sector, there is a multitude of ways of retiring earlier than this normal age of $65 .{ }^{9}$ There is disability protection, which is a much more plausible route to retirement than in the private sector system as the screening is considered to be much less severe. Most importantly however, it is possible to opt for an incomplete career and retire at 60. For some particular categories of workers, the normal retirement age is lower than 65 , and early retirement provisions are sometimes extremely generous (military servicemen, teachers...). Public sector pensions are based on the income earned by an individual during the last 5 years before retirement. Benefits are computed according to a rather complicated formula but can never exceed 75 percent of the average wages over the last five years. The benefit formula can be represented as follows:

Benefit $=$ average wage over last five years $* \min [$ fract $; 0.75]$

Where fract is a fraction with a numerator consisting of the number of years the person worked in the public service, and the denominator being a benefit accrual factor. This latter benefit accrual factor, also called "tantième", depends on the rank the person occupied in the hierarchy. This denominator ranges from 30 to 60, taking the value of 30 for the highestranking civil servants (high court judges, university professors...) and 60 for the lowest ranks. As in the private sector wage earner's scheme, the system is earnings-tested. The system also applies floors and ceilings which are however much more generous than for private sector retirement benefits. Most notably, higher income individuals get a much better deal in the public sector than in the private sector. This finding is even reinforced once we consider indexation rules, as public sector pensions are indexed on average wages ("péréquation"). Public servants therefore enjoy the benefits of productivity increases in the economy even beyond the moment when they actively contribute to them as workers.

\section{Self-employed}

The self-employed retirement scheme is the latest one to have been introduced, as it only exists since 1956. It is also the least generous of the three big social security systems with retirement benefits close to the level of the guaranteed minimum income (see below). It does Self-employed are not entitled to unemployment benefits, nor to early retirement benefits.

\footnotetext{
7 The system of the "aged unemployed" was reformed in July 2002. The rules were tightened for new entrants to the unemployment system, with grandfathering rules applicable to those already in the system. The minimum age for a full waiver of obligations under the unemployment insurance system was raised to 56. A new system of "mini-waiver" was introduced on the periodic visits to the unemployment insurance as of age 50, but the person still needs to ready to accept a job.

${ }^{8}$ Disability is not a major route towards early retirement due to rather stringent qualifying conditions and rather advanced screening.

${ }^{9}$ Currently, less than 15 per cent of civil servants retire at the age of 65 .
} 
Disability benefits exist, but both qualifying conditions and financial characteristics of the system make it a most unlikely exit route to retirement. For a very long time, old-age pensions have been independent of earnings levels. However, since 1984, the system is progressively being transformed to allow for a stronger link between contributions and benefits. Additional earnings past 1984 enter the pension computation formula at their correct value, instead of some fictive amount. Full benefits are available at age 65 for men with a complete earnings history of 45 years. However, anticipated retirement is possible as early as age 60 with an actuarial reduction of 5 percent per year of anticipation. As for the wage earners scheme, women are in a transitory phase, with the complete career requirement shifting from 40 years of work to 45, and normal retirement age from 60 to 65 .

The social security system of the self-employed is financed through two broad categories of income. First, there are direct social insurance contributions levied under the form of a tax of 16.7 percent on the first EUR 46,035 of income, and 12.27 percent on the income in the bracket between EUR 46,035 and EUR 67,352. Income above the latter threshold is not subject to social insurance taxation. More than 75 percent of the contributions raised using this social insurance taxation are used for the pension system of the self-employed, the remainder serves to cover health-care and other social insurance benefits for the selfemployed. Second, the federal government pays a large subsidy to the system that corresponds to approximately 37 percent of benefits.

\section{Guaranteed minimum income}

The guaranteed minimum income pensions are fully paid for by general government revenue, and are means-tested. This type of pension is only available after the legal retirement age.

\section{The model}

We opt for an approach of micro-simulation relying on the data and estimates already used in Dellis et alii (2002). The underlying data stem from five different sources, most of which are of administrative origin. The different data were merged using the national ID number that is the Belgian equivalent to the US Social Security number.

The first component of the data is the SFR (Fiscal Revenue Statistics) file, which are collected by the Finance Ministry, and then processed by the INS (National Statistics Office). We use the SFR files for the years 1989 to 1996 to extract all the information relevant for the computation of individual's tax liabilities. Variables available include wage income and income from other professional activities, household size and type, number of dependents in the household, age and income of spouse, social insurance transfers and private pension receipt, house ownership status (owner, renter), taxable real estate income, contributions to second and third pillar pensions... The second component is the CIP (Individual Pension Account) that includes all career information relevant for the wage earner pension computation: gross wages, days of work, days on social insurance programs, etc. The third and fourth components are the equivalent datasets for the self-employed and the civil servants, both of which files are less detailed than the one for the wage earners. Finally, information from the Census (1991) is merged in to determine education levels so as to be able to use survival tables that are education-level specific.

Dellis et alii (2002) used a multi-step sample selection procedure to obtain a sample of households where at least one member of the household is in the 50-64 age bracket and has not yet retired. A total of 21,818 households were used to analyze retirement decisions of men and women separately. Using the data, the authors estimated the parameters of retirement probit models. Among the explanatory variables in the estimation the authors paid a particular attention to financial incentive measures. To measure the impact of the social security 
systems incentives we use several different indicators. A first one is the concept of household social security wealth (SSW), which is the present discounted value of all future benefit flows from a given social security system. Discounting is done allowing both for time preference and mortality adjustments. Further, SSW also has to allow for the possibility of people being subject to different retirement income systems. The authors apply the official rules that exist for cumulating benefits from the three main public systems. Hence, the total SSW is the weighted sum of the different pathways to retirement available to the individual or the couple. The weights on the early retirement and the unemployment/disability routes correspond to the sum of observed frequencies of these routes among all people of any given age up to age 65, the public retirement system takes the residual weight. For wage earners, we add the unemployment insurance and disability insurance paths as the two systems produce very similar benefit structures. Doing so, we give an upper bound on incentives for people to retire as we render all of disability voluntary. Given the lack of information for the public sector, we consider as early retirees all people retiring before the age of 60 .

The next two incentive indicators are forward-looking measures. "Peak value" represents the difference between SSW at its peak and SSW today. The second forward-looking measure is the concept of "option value" such as defined by Stock and Wise (1990) that is based on a utility maximization framework. The utility function $V_{t}$ underlying the computation of the option value process can be summarized by the following mathematical expression:

$V_{t}(r)=\sum_{s=t}^{r-1} \beta^{s-t} Y_{s}^{\gamma}+\sum_{s=r}^{S} \beta^{s-t}\left(k B_{s}(r)\right)^{\gamma}$

where the first expression on the right hand side represents the utility derived from labor income $\mathrm{Y}$, and the second expression represents utility derived from retirement income $B_{s}(r) ; \beta$ is the time preference rate which we assume to be approximately 0.97 , which corresponds to a discount rate of 3 percent, $\gamma$ corresponds to a parameter of concavity and is set to $\gamma=0.75$. Finally, $k=1.5$ expresses the relative weight of utility of retirement income as compared to wage-income. It reflects the fact that the income without effort generates more utility than income with effort.

The concept of option value $G_{t}\left(r^{*}\right)$ is then defined as the difference in utility terms between retiring at the best point in the future $\left(r^{*}\right)$ and now $(t)$.

$G_{t}\left(r^{*}\right)=V_{t}\left(r^{*}\right)-V_{t}(t)$

The key estimates of the authors are summarized in the following tables. 
Table 1: Retirement Probits for Men

\begin{tabular}{|c|c|c|c|c|c|c|c|c|}
\hline & \multicolumn{4}{|c|}{ Peak Value } & \multicolumn{4}{|c|}{ Option Value } \\
\hline & \multicolumn{2}{|c|}{ Age } & \multicolumn{2}{|c|}{ Age Dummies } & \multicolumn{2}{|c|}{ Age } & \multicolumn{2}{|c|}{ Age Dummies } \\
\hline & Coef. & Std.Err. & Coef. & Std.Err. & Coef. & Std.Err. & Coef. & Std.Err. \\
\hline Intercept & -7.5957 & 0.2698 & -2.4346 & 0.1690 & -7.5110 & 0.3387 & -2.2976 & 0.1709 \\
\hline Incentive Measures & & & & & & & & \\
\hline$\overline{\text { SSW (1000's) }}$ & -0.0008 & 0.0003 & -0.0008 & 0.0003 & -0.0001 & 0.0003 & -0.0001 & 0.0003 \\
\hline Probability effect & $(-0.0079)$ & & $(-0.0082)$ & & $(-00008)$ & & $(-0.0001)$ & \\
\hline AC, PV, OV (1000’s) & -0.0380 & 0.0016 & -0.0364 & 0.0017 & -0.0392 & 0.0054 & -0.0327 & 0.0054 \\
\hline $\begin{array}{l}\text { Probability effect } \\
\text { Demographic Variables }\end{array}$ & $(-0.3769)$ & & $(-0.3505)$ & & $(-0.4111)$ & & $(-0.3383)$ & \\
\hline$\overline{\text { Age }}$ & 0.1049 & 0.0039 & & & 0.1050 & 0.0053 & & \\
\hline Married & 0.1027 & 0.0499 & 0.1026 & 0.0505 & 0.0294 & 0.0488 & 0.0342 & 0.0495 \\
\hline Active Spouse & -0.0501 & 0.0394 & -0.0515 & 0.0399 & -0.0857 & 0.0383 & -0.0839 & 0.0388 \\
\hline Age Difference & -0.0003 & 0.0039 & -0.0001 & 0.0039 & -0.0009 & 0.0038 & -0.0015 & 0.0039 \\
\hline $\begin{array}{l}\text { Dependent } \\
\text { Income Earnings Variables }\end{array}$ & -0.0999 & 0.0361 & -0.0911 & 0.0364 & -0.0729 & 0.0352 & -0.0754 & 0.0355 \\
\hline $\begin{array}{l}\text { Life Cycle Earnings } \\
\text {. }\end{array}$ & 0.0138 & 0.0066 & 0.0151 & 0.0068 & 0.0155 & 0.0066 & 0.0180 & 0.0068 \\
\hline Earnings (1000’s) & -0.0084 & 0.0012 & -0.0084 & 0.0012 & 0.0014 & 0.0018 & -0.0002 & 0.0018 \\
\hline Spouse Earnings (1000's) & 0.0043 & 0.0024 & 0.0044 & 0.0024 & 0.0037 & 0.0024 & 0.0031 & 0.0024 \\
\hline Age and Schemes Dummies & & & & & & & & \\
\hline$\overline{\text { Age51 }}$ & . & & 0.0523 & 0.0827 & & . & 0.0134 & 0.0808 \\
\hline Age52 & . & & 0.2779 & 0.0779 & & . & 0.2289 & 0.0763 \\
\hline Age53 & . & & 0.3191 & 0.0788 & & . & 0.2087 & 0.0773 \\
\hline Age54 & . & & 0.4516 & 0.0773 & & . & 0.2871 & 0.0760 \\
\hline Age55 & . & & 0.6751 & 0.0720 & & . & 0.5664 & 0.0718 \\
\hline Age56 & . & & 0.6429 & 0.0740 & & . & 0.5003 & 0.0745 \\
\hline Age57 & . & & 0.8546 & 0.0723 & & . & 0.7359 & 0.0738 \\
\hline Age58 & . & & 1.0048 & 0.0734 & & . & 0.8659 & 0.0760 \\
\hline Age59 & . & & 0.7310 & 0.0833 & . & . & 0.4475 & 0.0869 \\
\hline Age60 & . & & 1.4439 & 0.0745 & . & . & 1.4456 & 0.0816 \\
\hline Age61 & . & & 1.4396 & 0.0806 & . & . & 1.4302 & 0.0876 \\
\hline Age62 & . & & 0.9767 & 0.0958 & . & . & 0.9868 & 0.1028 \\
\hline Age63 & . & & 1.0380 & 0.1023 & . & . & 1.0364 & 0.1097 \\
\hline Age64 & & & 0.9208 & 0.1129 & & & 0.9320 & 0.1198 \\
\hline Age65 & & & 1.9180 & 0.1083 & & & 1.9801 & 0.1191 \\
\hline Civil Servant & 0.6314 & 0.1258 & 0.6177 & 0.1277 & 0.3850 & 0.1254 & 0.3858 & 0.1281 \\
\hline Self-Employed & -0.0328 & 0.1235 & -0.0216 & 0.1254 & -0.0408 & 0.1244 & -0.0396 & 0.1271 \\
\hline Pseudo $\mathrm{R}^{2}$ & & 0.1901 & & 0.2067 & & 0.1512 & & 0.1741 \\
\hline
\end{tabular}

Source: Dellis et alii (2002), Financial values in US\$ at the exchange rate of 0,942 EUR/US\$ of $31 / 12 / 1999$ 
Table 2: Retirement Probits for Women

\begin{tabular}{|c|c|c|c|c|c|c|c|c|}
\hline & \multicolumn{4}{|c|}{ Peak Value } & \multicolumn{4}{|c|}{ Option Value } \\
\hline & \multicolumn{2}{|c|}{ Age } & \multicolumn{2}{|c|}{ Age Dummies } & \multicolumn{2}{|c|}{ Age } & \multicolumn{2}{|c|}{ Age Dummies } \\
\hline & Coef. & Std.Err. & Coef. & Std.Err. & Coef. & Std.Err. & Coef. & Std.Err. \\
\hline $\begin{array}{l}\text { Intercept } \\
\text { Incentive Measures }\end{array}$ & -6.2897 & 0.4100 & -1.8504 & 0.2497 & -4.7976 & 0.5161 & -1.5951 & 0.2554 \\
\hline $\begin{array}{l}\text { SSW (1000's) } \\
\text { Probability effect }\end{array}$ & $\begin{array}{c}-0.0003 \\
(-0.0042)\end{array}$ & 0.0003 & $\begin{array}{c}-0.0001 \\
(-0.0001)\end{array}$ & 0.0004 & $\begin{array}{c}-0.0007 \\
(-0.0089)\end{array}$ & 0.0004 & $\begin{array}{c}-0.0004 \\
(-0.0048)\end{array}$ & 0.0004 \\
\hline $\begin{array}{l}\text { AC, PV, OV (1000's) } \\
\text { Probability effect } \\
\text { Demographic Variables }\end{array}$ & $\begin{array}{c}-0.0307 \\
(-0.3940)\end{array}$ & 0.0023 & $\begin{array}{c}-0.0222 \\
(-0.2868)\end{array}$ & 0.0024 & $\begin{array}{c}-0.0793 \\
(-1.0341)\end{array}$ & 0.0089 & $\begin{array}{c}-0.0651 \\
(-0.8434)\end{array}$ & 0.0091 \\
\hline Age & 0.0887 & 0.0060 & & & 0.0641 & 0.0080 & & \\
\hline Married & 0.2222 & 0.0708 & 0.2030 & 0.0725 & 0.2269 & 0.0709 & 0.2079 & 0.0729 \\
\hline Active & -0.0367 & 0.0552 & -0.0606 & 0.0566 & -0.0784 & 0.0544 & -0.0920 & 0.0560 \\
\hline Age Difference & 0.0206 & 0.0063 & 0.0145 & 0.0064 & 0.0288 & 0.0066 & 0.0226 & 0.0068 \\
\hline $\begin{array}{l}\text { Dependent } \\
\text { Income Earnings Variables }\end{array}$ & -0.1539 & 0.0586 & -0.1687 & 0.0590 & -0.1346 & 0.0580 & -0.1575 & 0.0587 \\
\hline Life Cycle Earnings & 0.0081 & 0.0104 & 0.0062 & 0.0106 & 0.0069 & 0.0106 & 0.0053 & 0.0107 \\
\hline Earnings (1000’s) & -0.0090 & 0.0027 & -0.0084 & 0.0027 & 0.0125 & 0.0038 & 0.0102 & 0.0039 \\
\hline $\begin{array}{l}\text { Spouse Earnings (1000's) } \\
\text { Age and Schemes Dummies }\end{array}$ & -0.0021 & 0.0020 & -0.0017 & 0.0020 & -0.0011 & 0.0020 & -0.0010 & 0.0021 \\
\hline$\overline{\text { Age51 }}$ & . & & 0.0094 & 0.0923 & & & -0.0462 & 0.0922 \\
\hline Age52 & . & & 0.2391 & 0.0877 & & . & 0.1767 & 0.0876 \\
\hline Age53 & . & & 0.3247 & 0.0897 & & . & 0.2195 & 0.0899 \\
\hline Age54 & . & & 0.2192 & 0.0951 & & . & 0.0871 & 0.0955 \\
\hline Age55 & . & & 0.4942 & 0.0888 & & . & 0.3306 & 0.0906 \\
\hline Age56 & . & & 0.3489 & 0.0942 & & . & 0.1500 & 0.0973 \\
\hline Age57 & . & & 0.5099 & 0.0951 & & . & 0.2681 & 0.1001 \\
\hline Age 58 & . & & 0.3334 & 0.1060 & . & . & 0.0456 & 0.1128 \\
\hline Age59 & . & & 0.2208 & 0.1161 & . & . & -0.1246 & 0.1261 \\
\hline Age60 & . & & 1.4579 & 0.0973 & . & . & 1.2533 & 0.1123 \\
\hline Age61 & . & & 1.6646 & 0.1124 & . & . & 1.4447 & 0.1243 \\
\hline Age62 & . & & 0.5275 & 0.1795 & . & . & 0.2841 & 0.1881 \\
\hline Age63 & . & & 0.4805 & 0.1976 & & . & 0.2177 & 0.2072 \\
\hline Age64 & 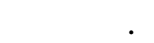 & & 0.9965 & 0.1988 & & & 0.6746 & 0.2108 \\
\hline Age65 & & & 1.3057 & 0.2116 & & & 1.0055 & 0.2218 \\
\hline Civil S & 0.2851 & 0.1224 & 0.2128 & 0.1248 & 0.1541 & 0.1228 & 0.1287 & 0.1252 \\
\hline Self-Employed & -0.2508 & 0.1292 & -0.2766 & 0.1319 & -0.2041 & 0.1300 & -0.2281 & 0.1330 \\
\hline Pseudo $\mathrm{R}^{2}$ & & 0.1536 & & 0.1918 & & 0.1365 & & 0.1860 \\
\hline
\end{tabular}

Source: Dellis et alii (2002), Financial values in US\$ at the exchange rate of 0,942 EUR/US $\$$ of $31 / 12 / 1999$ 


\section{Simulation methodology}

For our simulations purposes, we restrict our attention to a sub sample of the previously discussed dataset. We use a cross-section of individuals instead of the entire age range 50-64. More specifically, we consider pre-retirement age workers (male and female) aged 50 and then age them forward. We also include their spouses in the analysis. More specifically, we select all 50 year-old men and 50 year-old single females of the sample. Married 50 year-old females are excluded from the sample to avoid double counting, as our sample will account for the fiscal impact of all married females. This way, the cohort can be defined as a representative sample of the Belgian 50 year-old workers and their spouses. To ensure a sufficient sample size, we use a synthetic age 50 cohort made up of individuals aged 50 in 1993, 1994 or 1995. This gives us a total sample size of 4927 individuals, 2515 men, 2020 dependent women and 392 working women.

We first estimate the probability that each worker will exit the labor force via death or retirement at each future age. Exit probabilities are computed using the estimates of table 1 under the baseline setting with regards to all variables, including the SSW and peak and option value indicators. Spouses are supposed to retire at the early retirement age of the corresponding retirement scheme. In a second step, all these probabilities then serve as weights in the computation of the present discounted value (PDV) of the in - and outflows from the government budget. The financial flows considered are all flows from age 50 up until death. ${ }^{10}$ This marks a difference with respect to Dellis et alii (2002) as we consider the full budgetary costs and benefits of the synthetic cohort as it ages. The total impact of individuals on the government's budget is measured as the difference between the outflows from the budget as measured by the flow of social security and other social insurance program benefits (unemployment and early retirement) and the inflows as measured by payroll, income and consumption taxes. Payroll taxes include health, retirement, unemployment, disability, professional sickness and workers compensation contributions.

Next to the abovementioned payroll taxes, we include income taxes on labor and pension income as well as indirect taxes under the form of VAT. We incorporate direct taxes in accordance with the Belgian Personal Income Tax Code IPP (Personal Income Tax), thus also including the favorable tax treatment of pension income. However, to render the computation feasible, we have fully individualized the tax accounts of husbands and wives while the tax code only allows a partial splitting of incomes of spouses. Further, we decided to ignore some other tax code provisions. For example, we left aside the possibility to itemize deductions in favor of the standard flat-rate deduction, and we ignore taxation of private annuity income. The likely impact of these simplifications is difficult to sign as these omissions are to some degree offsetting. As for the VAT part, we rely on consumption data by income quartiles from the Household Budget Survey of the INS. Using the expenditure shares of different products in the typical household consumption basket by income quartile and weighting the corresponding VAT rates accordingly, the INS data imply an average VAT rate by income of 10,65 percent for the lowest income quartile, 10,60 for the second, 10,04 for the third and 9,14 for the top income quartile. We apply these average rates for all age groups in a uniform way.

The concept of PDV is the basis for comparison among different policy reform scenarios. We do so by re-estimating the exit probabilities, benefits, contributions and taxes under several reforms proposals for both spouses to obtain new PDV estimates. We even break down the

\footnotetext{
${ }^{10}$ To ensure international comparability across different countries considered, we discount all financial variables back to the age of 55 using a 3 percent real discount rate.
} 
total effect of a reform on the PDV into its components: the mechanical budgetary effect (with unchanged retirement probabilities with respect to the pre-reform situation) and the fiscal implications of the behavioral effect. We use the terminology "fiscal implications of the behavioral effect" to measure the budgetary impact of the labor supply reactions (which is properly speaking the change in the behavior of the individual). Indeed, this distinction is rather important, as it is quite imaginable to have a strong labor supply reaction, while at the same time having a very limited budgetary impact thereof due to a high degree of actuarial neutrality.

\section{Simulation results}

We consider four different reforms. The first three reforms share the common feature that they are not intended as policy recommendations, but rather to allow international comparisons. The fourth simulation is an interesting country-specific reform of the retirement system, whose only aim is to illustrate the impact of a partial reform within the Belgian institutional setting. None of the four reforms however pursues an objective of budget neutrality with respect to the baseline, which corresponds to the current institutional setting and hence not necessarily to one that is viable in the long-run. Nor does any of these reforms aim at establishing a balanced and viable budget in the long-run. ${ }^{11}$ The first two reforms have already been explored in Dellis et alii (2002) with respect to their impact on the SSW and accrual variables. However, the present exercise distinguishes itself clearly from the previous results as it incorporates a complete analysis of all budgetary implications of a retirement system change.

The first reform is called the "plus three years" reform and consists in a simple increase by three years of all key parameters in all retirement and early retirement systems in the country. Thus, the early and the normal entitlement ages are increased by 3 years, as is the length of a normal career from 45 to 48 years. All other system characteristics remain unchanged. Implicitly, this approach includes the rather implausible condition that unemployment benefits are totally absent from the landscape between the ages of 50 and 53 .

The second reform, the so-called "common reform", creates a system that is identical across all countries. The common system has a benefit equal to 60 percent of average real lifetime earnings at normal retirement age (NRA) that is defined to be at age 65. Past wages are deflated using real wage indexing. Average lifetime earnings are supposed to correspond to the highest 40 years of indexed earnings during an individual's working life. In case a worker has less than 40 years of earnings, zeros are averaged in, while a career longer than 40 years has an impact on the real average lifetime wage through a dropout year provision. Early retirement is available as of the age of 60 (ERA), with an actuarial adjustment of 6 percent per year of anticipation. Benefits thus defined ae capped at the $90^{\text {th }}$ percentile of the wage distribution for men. Benefits are subject to income taxation under the same rules as in the pre-reform world. Survivor benefits are paid out at a rate of 100 percent of workers benefits, but are reduced one for one for every euro of own benefits the recipients receives on his/her own earnings history. No other benefits are available, which thus represents a rather dramatic change in benefit availability before the age of 60 in a country like Belgium.

The third reform is called the "actuarial adjustment reform". The approach can be located midway between the previous two reforms and hence its results will be presented in second place in the Tables and Figures that follow. The reform keeps the structure of the sectoral social security schemes unchanged with respect to the present, including eligibility ages, minimum contribution periods, as well as formulae for the computation of the basic benefits. However, the reform introduces an actuarial adjustment factor to vary the benefit flow as a

\footnotetext{
${ }^{11}$ Hopefully they are more viable than the status quo.
} 
function of the exit age of the labor force, or expressed differently the entry age into retirement. The linear adjustment factor is of 6 percent per year of deviation from the normal retirement age, which is currently 65 under all 3 major Belgian sectoral pension schemes. Means-tested programs as well as survivor and spousal benefits are kept unchanged in their generosity with respect to the baseline situation, unless they are directly linked to the worker's own benefits. The age dependent nature of workers' retirement benefits thus implies a relative increase in the attractiveness of means-tested programs for younger retirees.

The last reform considered is a "Belgian-specific" reform. We consider a reform where the government reforms the current wage-earner scheme by no longer crediting years spent on all kinds of social insurance programs such as unemployment insurance, disability insurance and early retirement in the individuals pension record. All other system characteristics are supposed to remain unchanged, thus leaving the early retirement and unemployment paths into retirement intact. Thus people will be confronted with incomplete careers at the end of their working life. There is thus a smaller buffering effect against income shocks on a lifetime basis. Another way of looking at the problem is to notice that the reform introduces a stronger link between contributions and benefits, and hence reinforces the pure insurance aspect of the system.

For evaluating the results of the first three simulations, we use simulation methods S1, S2 and S3 of Dellis et alii (2002). Method S1 relies on the estimates with a linear age trend, which is unchanged by the reform. It adjusts the eligibility probabilities for unemployment or early retirement benefit receipt and applies the post-reform incentive and PDV measures. Method S2 is based on the age dummy model without a shift of the dummies. It is essentially the same as S1. However, the age dummy effects are far from linear and hence it is possible that these dummies better pick up the non-linearities in the various retirement and early retirement systems, or alternatively that tastes for leisure are not a linear function of age. Method S3 is based on the age dummy models and considers a shift of dummies to perform the simulations in a specific way for each one of the reforms. For the first reform, all age dummies are shifted upwards by three years. This also applies to those dummies at ages lower than the earliest eligibility age so that the entire retirement hazard shifts forward. For the common reform we proceed in a similar way, but the impact of age dummies is modify in a different way. On the one hand, given that in this policy simulation alternative retirement pathways are assumed out, we apply the age 51 dummy to all ages up to the age 59 , just prior to the early retirement age, and this both for men and women. On the other hand, we keep the effect of age 60 and 65 dummies unchanged assuming that the common reform will not affect individual behavior at these particular ages. Finally, using these two dummy values we imputed the values of the intermediary dummies, from age 61 to age 64, assuming a smooth path trend. As for the actuarial adjustment reform and the Belgian reform, methods S2 and S3 are equivalent, as there is no change in the key early and normal retirement ages from the baseline scenario to the reform situation.

A first noticeable finding is that the PDV of benefits minus taxes is negative in all cases considered in Table 3, thus the results tell us that our cohort is a net contributor (benefits minus taxes and contributions) to the public finances. At first sight, this result looks rather surprising as it is contrary to intuition and contrary to the finding we can observe when purely focusing on the social security system. However, several factors help explain it. First, it is important to note that direct taxation is extremely heavy in Belgium. Second, discounting plays an important role in the results. While taxes are essentially front-loaded in the Belgian tax and social insurance system, benefits are rather back-loaded from a life-cycle perspective. Third, and last it is important to notice that we consider only a single outflow of the government budget, while we consider a large array of inflows into the budget. For example, 
Table 3 : Total Fiscal Impact of Reform (in EUR per worker)

\begin{tabular}{|c|c|c|c|c|c|c|c|c|c|}
\hline & \multicolumn{5}{|c|}{ PDV } & \multicolumn{4}{|c|}{ Total Change Relative to Base } \\
\hline & Base & $\begin{array}{c}\text { Plus } 3 \text { years } \\
\text { Reform }\end{array}$ & $\begin{array}{l}\text { Act. Adjust. } \\
\text { Reform }\end{array}$ & $\begin{array}{l}\text { Common } \\
\text { Reform }\end{array}$ & $\begin{array}{l}\text { Belgian } \\
\text { Reform }\end{array}$ & $\begin{array}{c}\text { Plus } 3 \text { years } \\
\text { Reform }\end{array}$ & $\begin{array}{l}\text { Act. Adjust. } \\
\text { Reform }\end{array}$ & $\begin{array}{c}\text { Common } \\
\text { Reform }\end{array}$ & $\begin{array}{l}\text { Belgian } \\
\text { Reform }\end{array}$ \\
\hline & & \multicolumn{8}{|c|}{ Peak Value - S1 } \\
\hline Benefits & 146581 & 131131 & 120265 & 114111 & 141371 & $-10,5 \%$ & $-18,0 \%$ & $-22,2 \%$ & $-3,6 \%$ \\
\hline Taxes: Payroll & 58408 & 61934 & 64857 & 63625 & 59312 & $6,0 \%$ & $11,0 \%$ & $8,9 \%$ & $1,5 \%$ \\
\hline Taxes: Income & 80843 & 84908 & 85741 & 76989 & 81004 & $5,0 \%$ & $6,1 \%$ & $-4,8 \%$ & $0,2 \%$ \\
\hline Taxes: VAT & 19313 & 18744 & 18346 & 18280 & 19056 & $-2,9 \%$ & $-5,0 \%$ & $-5,4 \%$ & $-1,3 \%$ \\
\hline \multirow[t]{2}{*}{ Taxes: Total } & 158564 & 165586 & 168944 & 158893 & 159372 & $4,4 \%$ & $6,5 \%$ & $0,2 \%$ & $0,5 \%$ \\
\hline & & \multicolumn{8}{|c|}{ Peak Value - S2 } \\
\hline Benefits & 147667 & 129241 & 120458 & 114115 & 142326 & $-12,5 \%$ & $-18,4 \%$ & $-22,7 \%$ & $-3,6 \%$ \\
\hline Taxes: Payroll & 57307 & 61548 & 63516 & 62234 & 58166 & $7,4 \%$ & $10,8 \%$ & $8,6 \%$ & $1,5 \%$ \\
\hline Taxes: Income & 79472 & 84478 & 83977 & 75300 & 79542 & $6,3 \%$ & $5,7 \%$ & $-5,3 \%$ & $0,1 \%$ \\
\hline Taxes: VAT & 19339 & 18759 & 18304 & 18250 & 19088 & $-3,0 \%$ & $-5,4 \%$ & $-5,6 \%$ & $-1,3 \%$ \\
\hline Taxes: Total & 156119 & 164785 & 165797 & 155784 & 156796 & $5,6 \%$ & $6,2 \%$ & $-0,2 \%$ & $0,4 \%$ \\
\hline & & \multicolumn{8}{|c|}{ Peak Value - S3 } \\
\hline Benefits & 147667 & 129248 & 120458 & 114735 & 142326 & $-12,5 \%$ & $-18,4 \%$ & $-22,3 \%$ & $-3,6 \%$ \\
\hline Taxes: Payroll & 57307 & 66872 & 63516 & 65697 & 58166 & $16,7 \%$ & $10,8 \%$ & $14,6 \%$ & $1,5 \%$ \\
\hline Taxes: Income & 79472 & 90849 & 83977 & 79219 & 79542 & $14,3 \%$ & $5,7 \%$ & $-0,3 \%$ & $0,1 \%$ \\
\hline Taxes: VAT & 19339 & 19264 & 18304 & 18479 & 19088 & $-0,4 \%$ & $-5,4 \%$ & $-4,5 \%$ & $-1,3 \%$ \\
\hline \multirow[t]{2}{*}{ Taxes: Total } & 156119 & 176985 & 165797 & 163394 & 156796 & $13,4 \%$ & $6,2 \%$ & $4,7 \%$ & $0,4 \%$ \\
\hline & & \multicolumn{8}{|c|}{ Option Value - S1 } \\
\hline Benefits & 145711 & 128967 & 115129 & 112722 & 140496 & $-11,5 \%$ & $-21,0 \%$ & $-22,6 \%$ & $-3,6 \%$ \\
\hline Taxes: Payroll & 58981 & 62731 & 63293 & 62491 & 59439 & $6,4 \%$ & $7,3 \%$ & $6,0 \%$ & $0,8 \%$ \\
\hline Taxes: Income & 82021 & 85663 & 81469 & 76800 & 81702 & $4,4 \%$ & $-0,7 \%$ & $-6,4 \%$ & $-0,4 \%$ \\
\hline Taxes: VAT & 20333 & 19605 & 19034 & 19039 & 20014 & $-3,6 \%$ & $-6,4 \%$ & $-6,4 \%$ & $-1,6 \%$ \\
\hline \multirow[t]{2}{*}{ Taxes: Total } & 161335 & 168000 & 163795 & 158330 & 161155 & $4,1 \%$ & $1,5 \%$ & $-1,9 \%$ & $-0,1 \%$ \\
\hline & & \multicolumn{8}{|c|}{ Option Value - S2 } \\
\hline Benefits & 145529 & 126448 & 115273 & 112682 & 140577 & $-13,1 \%$ & $-20,8 \%$ & $-22,6 \%$ & $-3,4 \%$ \\
\hline Taxes: Payroll & 59882 & 63806 & 63223 & 62574 & 60228 & $6,6 \%$ & $5,6 \%$ & $4,5 \%$ & $0,6 \%$ \\
\hline Taxes: Income & 82656 & 86643 & 80937 & 76560 & 82286 & $4,8 \%$ & $-2,1 \%$ & $-7,4 \%$ & $-0,4 \%$ \\
\hline Taxes: VAT & 20354 & 19549 & 18996 & 19001 & 20043 & $-4,0 \%$ & $-6,7 \%$ & $-6,6 \%$ & $-1,5 \%$ \\
\hline \multirow[t]{2}{*}{ Taxes: Total } & 162891 & 169998 & 163156 & 158136 & 162557 & $4,4 \%$ & $0,2 \%$ & $-2,9 \%$ & $-0,2 \%$ \\
\hline & & \multicolumn{8}{|c|}{ Option Value - S3 } \\
\hline Benefits & 145529 & 127191 & 115273 & 113163 & 140577 & $-12,6 \%$ & $-20,8 \%$ & $-22,2 \%$ & $-3,4 \%$ \\
\hline Taxes: Payroll & 59882 & 68464 & 63223 & 64393 & 60228 & $14,3 \%$ & $5,6 \%$ & $7,5 \%$ & $0,6 \%$ \\
\hline Taxes: Income & 82656 & 92441 & 80937 & 77924 & 82286 & $11,8 \%$ & $-2,1 \%$ & $-5,7 \%$ & $-0,4 \%$ \\
\hline Taxes: VAT & 20354 & 20050 & 18996 & 19312 & 20043 & $-1,5 \%$ & $-6,7 \%$ & $-5,1 \%$ & $-1,5 \%$ \\
\hline Taxes: Total & 162891 & 180955 & 163156 & 161629 & 162557 & $11,1 \%$ & $0,2 \%$ & $-0,8 \%$ & $-0,2 \%$ \\
\hline
\end{tabular}


we consider all tax revenues even though only part of them help towards financing goods and services for the elderly while some public subsidies to the old (more generous reimbursement of health expenditures, nursing home care, long-term care, public transportation, ...) do not appear on the outflow side.

When measuring the impact of the various reforms on the different components reported in Table 3 as a proportion of the baseline benefits, we find that the common reform is the most powerful one in terms of the change in the PDV of benefits, followed by the actuarial adjustment reform. This finding is not too surprising given the fact that Belgians leave the workforce rather early in their life-cycle, and hence are fully hit by the actuarial adjustments (actuarial adjustment and common reforms) and the reduced availability of benefits before the early retirement age of the social security system (common reform). The same lack of availability of benefits before the age of 60 is also the main cause of the drop in income tax receipt under the common reform, with a drop of 5 percent in all but the PV S3 simulation methodology. Overall, it is fair to say that the impact as measured using the PV and OV estimates are rather similar.

As for the Belgian reform, it only displays a rather modest effect in terms of its impact on the value of the PDV of benefits, while its likely cost in terms of redistribution is rather heavy. Several reasons help explain this result. First, of all, the reform only affects the wage-earners schemes, which casts the order of magnitude of the change in a different light. Further, the effect of the changes only affects one particular form of retirement income, and does not affect payments either through the unemployment or the early retirement systems. Hence, the changes only affect people retiring early through the change of the benefits they receive starting at age 65 , as the latter remains the age at which people are switched into the retirement system. Therefore, for a person aged 50, the effect of the changes only apply on income he sarts receiving in 15 years time, and this with a 3 percent real discount factor per year. For a person aged 65, nothing much changes in terms of benefit receipt, unless obviously the person had experienced a longer spell on a social insurance program in the past. Finally, the reform is somewhat buffered against by the availability of means-tested minimum benefits, which increasingly become interesting substitutes for people with incomplete earnings histories due to sickness, unemployment, disability, ...

To illustrate the distinction between behavioral and mechanical effects of a reform, let us focus on the net benefits an individual receives in a world of absolute certainty with respect to the life span. We denote them as $b$ and they depend on a policy parameter $x$ and on the age of retirement $z$, itself a function of $x$. We thus have

$$
b(x, z(x))
$$

A reform consists of a change from $x$ to $x^{\prime}$. The effect (Diff) of such a reform is:

$$
D i f f=b\left(x^{\prime}, z\left(x^{\prime}\right)\right)-b(x, z(x))
$$

We can decompose Diff into two parts Diff ${ }^{n}$ and Diff ${ }^{p}$ corresponding to the mechanical and behavioral effects with

$$
\begin{aligned}
& \operatorname{Diff}^{m}=b\left(x^{\prime}, z(x)\right)-b(x, z(x)) \\
& \operatorname{Diff}^{b}=b\left(x^{\prime}, z\left(x^{\prime}\right)\right)-b\left(x^{\prime}, z(x)\right)
\end{aligned}
$$

and Diff ${ }^{m}+$ Diff $^{b}=$ Diff

Table 4 displays a strong behavioral effect for all scenarios. This is particularly true when considering the first reform using simulation technique S3 where the net behavioral effect of 
benefits minus contributions as a proportion of base benefits is anyway the most powerful (more than a quarter of base benefits). Table 4 shows that the behavioral response for both 
Table 4 : Decomposition of the Total Effect of Reform (in EUR per worker)

\begin{tabular}{|c|c|c|c|c|c|c|c|c|c|c|c|c|}
\hline & \multicolumn{12}{|c|}{ Change in PDV } \\
\hline & \multicolumn{3}{|c|}{ Plus 3 years } & \multicolumn{3}{|c|}{ Actuarial Adjustment } & \multicolumn{3}{|c|}{ Common Reform } & \multicolumn{3}{|c|}{ Belgian Reform } \\
\hline & $\begin{array}{l}\text { Mech- } \\
\text { anical }\end{array}$ & $\begin{array}{l}\text { Behav- } \\
\text { ioral }\end{array}$ & Total & $\begin{array}{l}\text { Mech- } \\
\text { anical }\end{array}$ & $\begin{array}{l}\text { Behav- } \\
\text { ioral }\end{array}$ & $\begin{array}{c}\text { Total } \\
\text { Peak V }\end{array}$ & $\begin{array}{l}\text { Mech- } \\
\text { anical } \\
\mathbf{e}-\mathbf{S 1}\end{array}$ & $\begin{array}{c}\text { Behav- } \\
\text { ioral }\end{array}$ & Total & $\begin{array}{l}\text { Mech- } \\
\text { anical }\end{array}$ & $\begin{array}{c}\text { Behav- } \\
\text { ioral }\end{array}$ & Total \\
\hline Benefits & -19582 & 4132 & -15450 & -34745 & 8429 & -26316 & -35323 & 2853 & -32470 & -5073 & -137 & -5210 \\
\hline Total Taxes & -3592 & 10614 & 7022 & -10691 & 21070 & 10379 & -12849 & 13177 & 329 & -1360 & 2168 & 808 \\
\hline Net Change & -15990 & -6482 & -22472 & -24054 & -12642 & -36696 & -22474 & -10325 & -32799 & -3713 & -2305 & -6018 \\
\hline \multirow[t]{2}{*}{ Change as a $\%$ of Base Benefits } & $-10,9 \%$ & $-4,4 \%$ & $-15,3 \%$ & $-16,4 \%$ & $-8,6 \%$ & $-25,0 \%$ & $-15,3 \%$ & $-7,0 \%$ & $-22,4 \%$ & $-2,5 \%$ & $-1,6 \%$ & $-4,1 \%$ \\
\hline & \multicolumn{12}{|c|}{ Peak Value - S2 } \\
\hline Benefits & -20635 & 2210 & -18425 & -36142 & 8934 & -27208 & -36498 & 2945 & -33552 & -5242 & -99 & -5341 \\
\hline Total Taxes & -3787 & 12453 & 8666 & -10963 & 20641 & 9678 & -13028 & 12692 & -335 & -1416 & 2092 & 677 \\
\hline Net Change & -16849 & -10243 & -27092 & -25179 & -11707 & -36886 & -23470 & -9747 & -33217 & -3826 & -2191 & -6018 \\
\hline \multirow[t]{2}{*}{ Change as a $\%$ of Base Benefits } & $-11,4 \%$ & $-6,9 \%$ & $-18,3 \%$ & $-17,1 \%$ & $-7,9 \%$ & $-25,0 \%$ & $-15,9 \%$ & $-6,6 \%$ & $-22,5 \%$ & $-2,6 \%$ & $-1,5 \%$ & $-4,1 \%$ \\
\hline & \multicolumn{12}{|c|}{ Peak Value - S3 } \\
\hline Benefits & -20635 & 2217 & -18418 & -36142 & 8934 & -27208 & -36498 & 3566 & -32932 & -5242 & -99 & -5341 \\
\hline Total Taxes & -3787 & 24653 & 20866 & -10963 & 20641 & 9678 & -13028 & 20302 & 7275 & -1416 & 2092 & 677 \\
\hline Net Change & -16849 & -22436 & -39284 & -25179 & -11707 & -36886 & -23470 & -16737 & -40206 & -3826 & -2191 & -6018 \\
\hline \multirow[t]{2}{*}{ Change as a $\%$ of Base Benefits } & $-11,4 \%$ & $-15,2 \%$ & $-26,6 \%$ & $-17,1 \%$ & $-7,9 \%$ & $-25,0 \%$ & $-15,9 \%$ & $-11,3 \%$ & $-27,2 \%$ & $-2,6 \%$ & $-1,5 \%$ & $-4,1 \%$ \\
\hline & \multicolumn{12}{|c|}{ Option Value - S1 } \\
\hline Benefits & -18530 & 1785 & -16745 & -33786 & 3203 & -30583 & -34554 & 1565 & -32990 & -4947 & -268 & -5216 \\
\hline Total Taxes & -3657 & 10323 & 6666 & -10882 & 13343 & 2461 & -13047 & 10042 & -3004 & -1389 & 1210 & -179 \\
\hline Net Change & -14873 & -8538 & -23410 & -22904 & -10140 & -33044 & -21508 & -8478 & -29986 & -3558 & -1478 & -5036 \\
\hline \multirow[t]{2}{*}{ Change as a $\%$ of Base Benefits } & $-10,2 \%$ & $-5,9 \%$ & $-16,1 \%$ & $-15,7 \%$ & $-7,0 \%$ & $-22,7 \%$ & $-14,8 \%$ & $-5,8 \%$ & $-20,6 \%$ & $-2,4 \%$ & $-1,0 \%$ & $-3,5 \%$ \\
\hline & \multicolumn{12}{|c|}{ Option Value - S2 } \\
\hline Benefits & -18931 & -150 & -19081 & -33102 & 2846 & -30256 & -34194 & 1346 & -32848 & -4729 & -223 & -4952 \\
\hline Total Taxes & -3743 & 10849 & 7107 & -10764 & 11029 & 265 & -13036 & 8280 & -4755 & -1307 & 973 & -334 \\
\hline Net Change & -15188 & -11000 & -26188 & -22338 & -8183 & -30521 & -21158 & -6934 & -28092 & -3422 & -1195 & -4618 \\
\hline \multirow[t]{2}{*}{ Change as a $\%$ of Base Benefits } & $-10,4 \%$ & $-7,6 \%$ & $-18,0 \%$ & $-15,3 \%$ & $-5,6 \%$ & $-21,0 \%$ & $-14,5 \%$ & $-4,8 \%$ & $-19,3 \%$ & $-2,4 \%$ & $-0,8 \%$ & $-3,2 \%$ \\
\hline & \multicolumn{12}{|c|}{ Option Value -S3 } \\
\hline Benefits & -18931 & 593 & -18338 & -33102 & 2846 & -30256 & -34194 & 1827 & -32367 & -4729 & -223 & -4952 \\
\hline Total Taxes & -3743 & 21806 & 18064 & -10764 & 11029 & 265 & -13036 & 11774 & -1262 & -1307 & 973 & -334 \\
\hline Net Change & -15188 & -21213 & -36401 & -22338 & -8183 & -30521 & -21158 & -9947 & -31105 & -3422 & -1195 & -4618 \\
\hline Change as a $\%$ of Base Benefits & $-10,4 \%$ & $-14,6 \%$ & $-25,0 \%$ & $-15,3 \%$ & $-5,6 \%$ & $-21,0 \%$ & $-14,5 \%$ & $-6,8 \%$ & $-21,4 \%$ & $-2,4 \%$ & $-0,8 \%$ & $-3,2 \%$ \\
\hline
\end{tabular}


OV and PV estimations of the latter scenario imply a fiscal impact of the behavioral response that represents more than 50 percent of the total effect, essentially because of the outright shift by 3 years of all dummies. At first sight it might be curious to have a fiscal implication of the behavioral effect that is negative, i.e. that the cohort's contribution to the government budget increases as a reaction to the change in its behavior. However, the finding is less surprising when we notice that another important variable has changed as a consequence of this change in behavior, notably the length of the working life. Hence, the "loss" of the cohort in terms of net benefits minus taxes has to be seen as a tradeoff for the "gain" in income due to a higher average working life.

Another puzzling point from Table 4 is the indetermination in the sign of the behavioral effect on the PDV of benefits. It is positive in most cases except for the Belgian Reform, as well as for the case of simulation methodology S2 in the Option Value model. Table 5 illustrates the decomposition by age of retirement of the fiscal implication of the behavioral effect on benefits for a median household facing the actuarial adjustment reform. It appears that the behavioral effect is negative until age 60 and then turns positive, the sign coming from the sign of the probability change. Even with the negative probability changes larger than the positive ones in absolute value, as is the case in our example, we can observe that the total behavioral effect for this household is positive. The structure of the post-reform PDV of benefits by age of exit of the labor force helps explain this finding. As the actuarial adjustment reform is much less penalizing in the age range 61-70 than between the ages of 50 and 60, the PDV of benefits is steeply increasing as a function of age of labor force exit and hence leads to a positive behavioral effect when aggregating up over all possible exit ages. The same reasoning can be applied to the common reform and to a certain level to the Belgian reform. In this case, as the structure of the post-reform PDV of benefits does not change a lot from the base case, the negative probability changes, which extend typically from 50 to 56 , create a larger behavioral effect than the positive one on the age range 57-70. As to the "Plus 3 years" reform, the probability changes are so erratic that no typical rules can be found.

Table 5 : Decomposition of the behavioral effect on benefits for a median household (Actuarial Adjustment Reform - Option Value - S2)

\begin{tabular}{|c|c|c|c|c|c|c|}
\hline \multirow[t]{3}{*}{ Age } & $\begin{array}{l}\text { PDV of } \\
\text { Benefits }\end{array}$ & $\begin{array}{l}\text { Probability } \\
\text { of Exit (\%) }\end{array}$ & $\begin{array}{l}\text { PDV of } \\
\text { Benefits }\end{array}$ & $\begin{array}{c}\text { Probability of } \\
\text { Exit }(\%)\end{array}$ & \multirow{3}{*}{$\begin{array}{l}\text { Probability } \\
\text { Change } \\
\text { (d)-(b)=(e) }\end{array}$} & \multirow{3}{*}{$\begin{array}{l}\text { Behavioral } \\
\text { Effect } \\
(\mathrm{e})^{*}(\mathrm{c})\end{array}$} \\
\hline & \multicolumn{2}{|c|}{ Base case } & \multicolumn{2}{|c|}{ Actuarial Adjustment Reform } & & \\
\hline & (a) & (b) & (c) & (d) & & \\
\hline 50 & 329538 & 0.82 & 224385 & 0.44 & -0.38 & -855 \\
\hline 51 & 337893 & 0.99 & 227271 & 0.53 & -0.47 & -1057 \\
\hline 52 & 347071 & 2.02 & 229978 & 1.09 & -0.92 & -2122 \\
\hline 53 & 354961 & 2.19 & 233078 & 1.17 & -1.02 & -2379 \\
\hline 54 & 362829 & 2.97 & 236653 & 1.59 & -1.38 & -3263 \\
\hline 55 & 369887 & 5.84 & 240407 & 3.32 & -2.51 & -6043 \\
\hline 56 & 376577 & 5.21 & 243768 & 3.01 & -2.20 & -5366 \\
\hline 57 & 383305 & 8.28 & 246404 & 4.98 & -3.30 & -8131 \\
\hline 58 & 388166 & 9.85 & 253870 & 6.62 & -3.23 & -8198 \\
\hline 59 & 393696 & 4.41 & 266432 & 3.14 & -1.27 & -3392 \\
\hline 60 & 398815 & 19.11 & 279171 & 18.42 & -0.69 & -1922 \\
\hline 61 & 389943 & 11.52 & 296357 & 14.09 & 2.57 & 7604 \\
\hline 62 & 389340 & 4.41 & 319259 & 5.86 & 1.45 & 4619 \\
\hline 63 & 386618 & 3.77 & 340224 & 5.56 & 1.79 & 6084 \\
\hline 64 & 383631 & 2.58 & 360614 & 4.15 & 1.58 & 5684 \\
\hline 65 & 381773 & 6.73 & 381773 & 12.05 & 5.33 & 20332 \\
\hline 66 & 356814 & 2.71 & 356814 & 4.86 & 2.15 & 7667 \\
\hline
\end{tabular}




\begin{tabular}{rrrrrrr}
\hline 67 & 333433 & 1.09 & 333433 & 1.96 & 0.86 & 2883 \\
68 & 311112 & 0.44 & 311112 & 0.79 & 0.35 & 1081 \\
69 & 289168 & 0.18 & 289168 & 0.32 & 0.14 & 404 \\
70 & 268414 & 0.12 & 268414 & 0.21 & 0.09 & 254 \\
\hline Total & & & & & & 13886 \\
\hline
\end{tabular}

Figures A1 to A7 in the appendix illustrate the effects of the "three-year-increase" reform along several different margins. Figure A1 displays the PDV of benefits per worker at any given age of retirement, as well as the impact thereon by the reform. Figure A2 summarizes the total of taxes paid by age of labor force exit. This graph again illustrates the fact that the elderly are still important contributors to the federal budget. This is particularly true for those working till relatively late in their life cycle, as the fiscal pressure on the productive factor labor is relatively high compared to the pressure on pension benefits. Figure A3 and A5 display the simulated patterns of labor force exit over the age range 50-70, which follows a rather smooth pattern for the S1 simulation methodology, and a more erratic one for simulation methodology S3. The role of the shift in the age dummies becomes evident in figure A5. Figures A4 and A6 display the age-specific impact of the reform, with a rather modest net change (PDV of benefits minus taxes) at all ages, whereas the change of the PDV of benefits is of varying sign and characterized by larger swings in magnitude. Clearly, the tax system (payroll, income and consumption) plays an important role in the determination of the sign and magnitude of the net contribution to the federal budget at all possible exit ages. Figure A7 illustrates the power of these fiscal implications as a proportion of GDP. The figure shows that the mechanical effects are approximately of the same size for all possible simulation methodologies, but that the difference between these reforms stems from the behavioral effect.

Figures B1-B3-B7, C1-C3-C7 and D1-D3-D7 in the appendix illustrate the key results for the other three reforms in terms of the changes in the PDV of benefits and in the retirement probabilities at the different ages, as well as the fiscal implications as a proportion of GDP. The latter indicator allows a comparison of the total budgetary effect of the various reforms in terms of a common measure. It appears that - budgetarily speaking - the actuarial adjustment reform is the most powerful reform in all cases excluding those relying on the S3 methodology. Even if it is the common reform that has the strongest impact on the level of benefits because of its inherent ineligibility to retirement benefits before the age 60, it is the actuarial adjustment reform that creates the strongest incentives for individuals to work longer. Indeed, a comparison of Figure C3 with Figure B3 shows that the retirement rate is lower for the actuarial adjustment reform before age 60 and a bit higher after this age.

\section{Distributional analysis}

Table 6 and Table 7 display the distributional implications of the reforms when splitting the population into 5 income categories. A common feature of the first three reforms is that the three middle earnings quintiles, hence the middle classes, bear the brunt of the reform. This is particularly true for the common reform, where the impact on the two extreme income quintiles is much less pronounced. The results are less extreme for the case of the plus -threeyear reform, where the changes of all income quintiles are relatively close to one another as expressed in these relative terms. The actuarial adjustment reform again is the middle ground. Only the lowest income quintile loses less in relative terms under this reform proposal.

The Belgian reform on the other hand has a very different redistributive pattern. While income quintiles 3 and 4 again face the largest proportional change as displayed in tables $\mathrm{Z}$, it is now the lowest income quintile that loses out more than the first and second income quintiles. The reasons for this finding are multiple. First, they are due to he way the reform 
only affects those that are on the wage-earner scheme. Hence it does not affect civil servants who have relatively high life-cycle earnings, hence making them relatively more numerous in the upper income quintiles. Second, the reform only touches those with incomplete careers, and hence essentially touches two categories of people. First, it affects those with unstable 

Table 6: Distributional Analysis (Option Value -S1 - in EUR per worker)

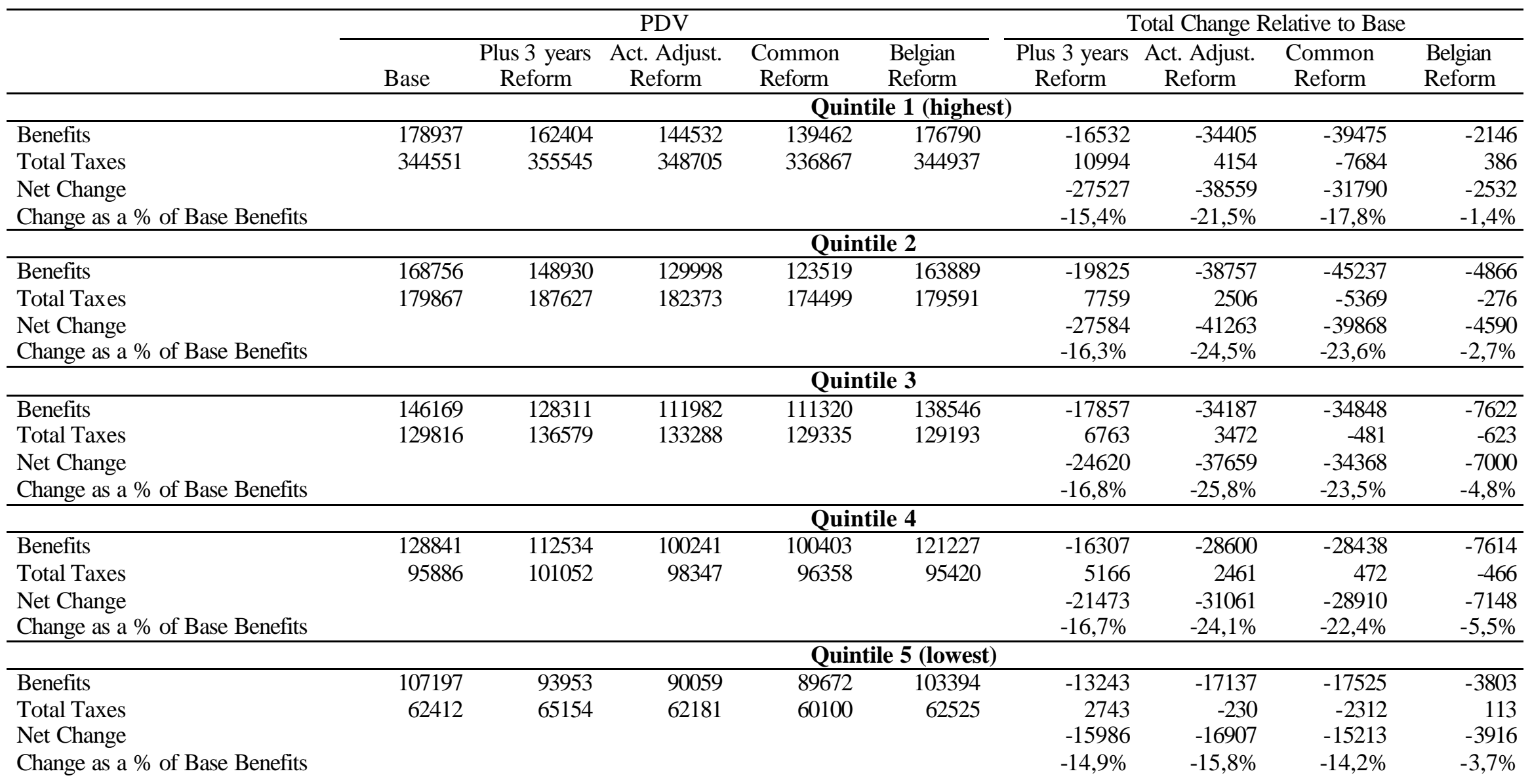


Table 7 : Distributional Analysis (Option Value-S3 - in EUR per worker)

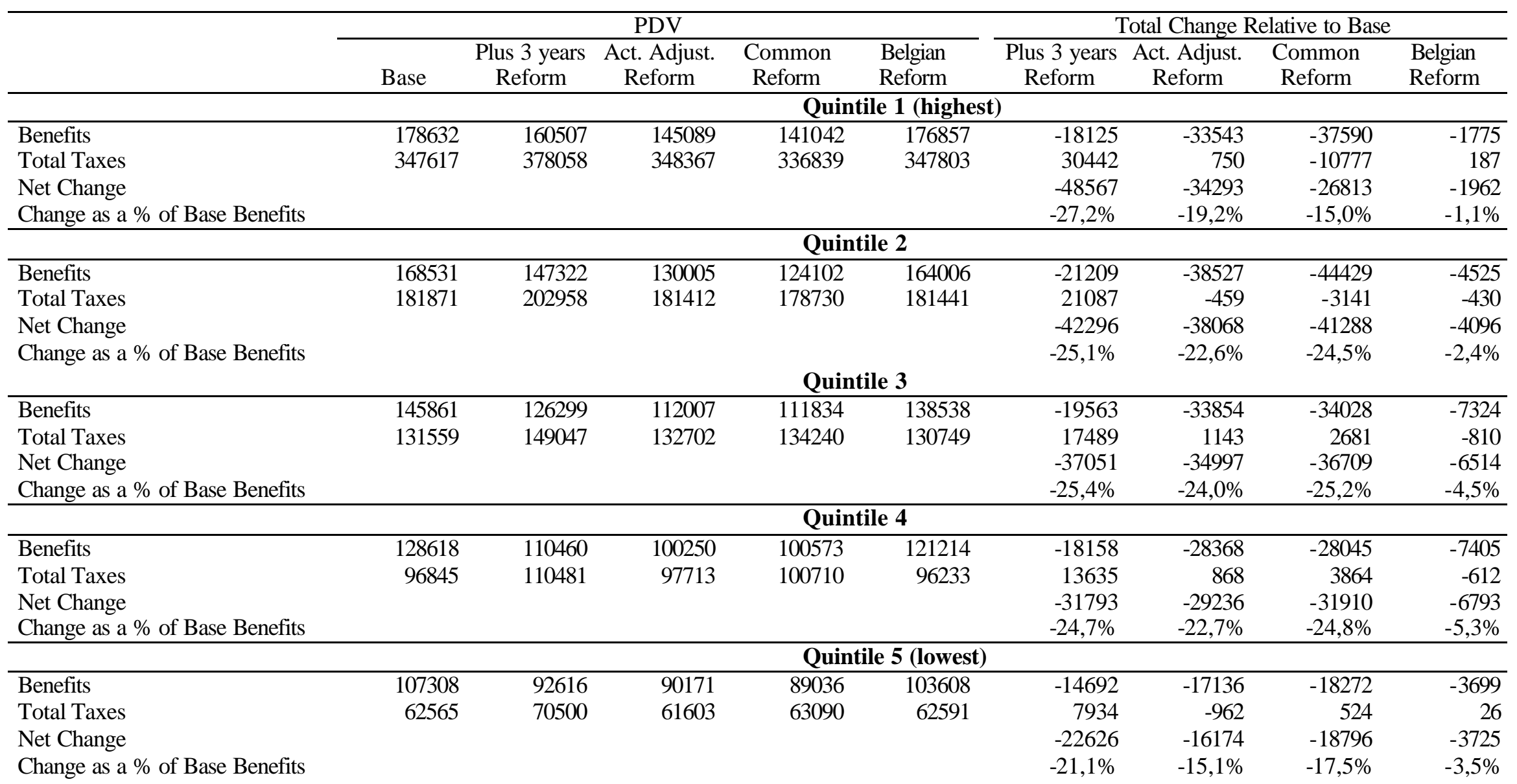


and incomplete career patterns due to sickness, invalidity, unemployment or accident. Second, it changes incentives for those choosing to retire early. Hence, the reform is less important for higher income white collars who face lower probabilities of layoff, accident, sickness and invalidity.

\section{Conclusions}

The analysis shows the large potential budgetary impact of various hypothetical reforms. These reforms, though clearly selected for comparative and illustrative purposes, illustrate the importance of behavioral effects that the citizens display when faced with a varying landscape in terms of the social insurance architecture. Different real-life reform alternatives are imaginable in the Belgian context. Any such real-life alternative will have to include - at least to some degree - some elements analyzed in our stylized scenarios, for example, changes in the key retirement ages, the use of actuarial adjustment factors and a convergence between the three main retirement systems, while at the same time not forgetting the labor demand side. The common reform admittedly looks somewhat unrealistic. In that sense, our "Belgian reform" is a first step in the direction of getting these hypothetical simulations closer to the field. By eliminating one particular aspect of our largely Bismarckian system, namely an aspect that is not insurance based, we reestablish a clearer link between contributions and benefits. The results indicate that even such a partial reform might have important consequences, not only in levels but also on the distributional side. The results of the present distributional analysis also illustrate the need to refine the analysis in future research.

However, we would like to insist on the fact that the analysis heavily relies on some assumptions we made, most notably the limitation to the cohort of 50 year olds and the steady state assumption, which both clearly limit the generality with which one can apply the above results to real-world proposals. Hence there is a clear need for further research to get the reform proposals closer in line with politically feasible and economically viable alternatives over the long run, as well as to check the robustness of our simulation approach.

The present paper shows that the social security system at large (i.e. including unemployment and disability insurance as well as early retirement schemes) induces Belgian workers to retire earlier than they ought to. Most reforms contemplated imply that we bring this comprehensive social security package closer to actuarial fairness. We realize that this is questionable and ought to be viewed as a first step towards a more complete analysis of reforms. Assume indeed that a fraction of these early retirees who draw benefits from disability benefits are truly disabled and a fraction of those drawing benefits from unemployment insurance are truly involuntarily unemployed. A good reform should attempt to identify these workers and let them benefit from social insurance. This may imply improving the audit and control procedures, particularly for unemployment. Then for the remaining early voluntary early retirees we would apply our alternative actuarial reforms.

\section{Bibliography}

Blöndal, S. and S. Scarpetta, (1998), Falling participation rates among older workers in the OECD countries, Paris.

Dellis, A., R. Desmet, A. Jousten and S. Perelman (2002), "Micro-modelling of retirement in Belgium", forthcoming in J. Gruber and D. Wise, eds., "', NBER and University of Chicago Press, Chicago

Institut National de Statistique (1995-1996), " Enquête sur les budgets des ménages", Bruxelles 
Jousten, A. and P. Pestieau (2000), "Labor mobility, redistributon and pension reform in Europe", forthcoming in Feldstein and Siebert, Coping with the pension crisis - where does Europe stand?, NBER and Chicago University Press, Chicago

OECD (1994), OECD Economic Survey: Belgium, Luxembourg, OECD, Paris

Pestieau, P. and J.-P. Stijns (1999), "Social Security and retirement in Belgium", in Gruber and Wise (1999), Social Security and retirement around the world, NBER and Chicago University Press, Chicago, 37-71.

Sneesens, H., F. Shadman and O. Pierrard (2002), "Effets des préretraites sur l'emploi", in CIFoP (2002), "Départs à la retraite et sécurité sociale", CIFoP, Charleroi

Stock, J. and D. Wise (1990), "Pensions, the option value of work, and retirement", Econometrica, 58(5), 1151-1180 
To order any of these papers in hard copy, see instructions at the end of this list. To subscribe to all NBER Working Papers or the papers in a single area, see instructions inside the back cover.

\begin{tabular}{|c|c|c|c|}
\hline Number & $\underline{\text { Author(s) }}$ & $\underline{\text { Title }}$ & $\underline{\text { Date }}$ \\
\hline 9436 & $\begin{array}{l}\text { Kenn Ariga } \\
\text { Kenji Matsui }\end{array}$ & Mismeasurement of the CPI & $1 / 03$ \\
\hline 9437 & Robert J. Gordon & $\begin{array}{l}\text { Hi-tech Innovation and Productivity Growth: Does } \\
\text { Supply Create Its Own Demand? }\end{array}$ & $1 / 03$ \\
\hline 9438 & $\begin{array}{l}\text { Lee Branstetter } \\
\text { Yoshiaki Nakamura }\end{array}$ & Is Japan's Innovative Capacity in Decline? & $1 / 03$ \\
\hline 9439 & $\begin{array}{l}\text { Elhanan Helpman } \\
\text { Marc J. Melitz } \\
\text { Stephen R. Yeaple }\end{array}$ & Export versus FDI & $1 / 03$ \\
\hline 9440 & Daniel S. Hamermesh & Routine & $1 / 03$ \\
\hline 9441 & Wayne E. Ferson & $\begin{array}{l}\text { Tests of Multifactor Pricing Models, Volatility } \\
\text { Bounds and Portfolio Performance }\end{array}$ & $1 / 03$ \\
\hline 9442 & $\begin{array}{l}\text { Francesco Caselli } \\
\text { Nicola Gennaioli }\end{array}$ & Dynastic Management & $1 / 03$ \\
\hline 9443 & $\begin{array}{l}\text { Pinelopi K. Goldberg } \\
\text { Nina Pavcnik }\end{array}$ & $\begin{array}{l}\text { The Response of the Informal Sector to Trade } \\
\text { Liberalization }\end{array}$ & $1 / 03$ \\
\hline 9444 & $\begin{array}{l}\text { Albert Ando } \\
\text { Dimitrios Christelis } \\
\text { Tsutomu Miyagawa }\end{array}$ & $\begin{array}{l}\text { Inefficiency of Corporate Investment and Distortion } \\
\text { of Savings Behavior in Japan }\end{array}$ & $1 / 03$ \\
\hline 9445 & $\begin{array}{l}\text { Kris James Mitchener } \\
\text { Ian W. McLean }\end{array}$ & The Productivity of the U.S. Since 1880 & $1 / 03$ \\
\hline 9446 & $\begin{array}{l}\text { David Cutler } \\
\text { Edward Glaeser } \\
\text { Jesse Shapiro }\end{array}$ & Why Have Americans Become More Obese? & $1 / 03$ \\
\hline 9447 & $\begin{array}{l}\text { Stephen Redding } \\
\text { Peter K. Schott }\end{array}$ & $\begin{array}{l}\text { Distance, Skill Deepening and Development: Will } \\
\text { Peripheral Countries Ever Get Rich? }\end{array}$ & $1 / 03$ \\
\hline 9448 & $\begin{array}{l}\text { Cameron Howell } \\
\text { Sarah E. Turner }\end{array}$ & $\begin{array}{l}\text { Legacies in Black and White: The Racial Composition } \\
\text { of the Legacy Pool }\end{array}$ & $1 / 03$ \\
\hline 9449 & Steven D. Levitt & $\begin{array}{l}\text { Testing Theories of Discrimination : Evidence from } \\
\text { Weakest Link }\end{array}$ & $1 / 03$ \\
\hline 9450 & David Flath & Regulation, Distribution Efficiency, and Retail Density & $1 / 03$ \\
\hline 9451 & Hilary Sigman & $\begin{array}{l}\text { Letting States do the Dirty Work: State Responsibility } \\
\text { for Federal Environmental Regulation }\end{array}$ & $1 / 03$ \\
\hline
\end{tabular}


To order any of these papers in hard copy, see instructions at the end of this list. To subscribe to all NBER Working Papers or the papers in a single area, see instructions inside the back cover.

\begin{tabular}{|c|c|c|c|}
\hline Number & $\underline{\text { Author(s) }}$ & $\underline{\text { Title }}$ & Date \\
\hline 9452 & $\begin{array}{l}\text { Amil Petrin } \\
\text { Kenneth Train }\end{array}$ & Omitted Product Attributes in Discrete Choice Models & $1 / 03$ \\
\hline 9453 & $\begin{array}{l}\text { Harvey S. Rosen } \\
\text { Stephen Wu }\end{array}$ & Portfolio Choice and Health Status & $1 / 03$ \\
\hline 9454 & $\begin{array}{l}\text { Alexander Ljungqvist } \\
\text { Matthew Richardson }\end{array}$ & $\begin{array}{l}\text { The cash flow, return and risk characteristics } \\
\text { of private equity }\end{array}$ & $1 / 03$ \\
\hline 9455 & $\begin{array}{l}\text { Michael Baker } \\
\text { Jonathan Gruber } \\
\text { Kevin Milligan }\end{array}$ & $\begin{array}{l}\text { Simulating the Response to Reform of } \\
\text { Canada's Income Security Programs }\end{array}$ & $1 / 03$ \\
\hline 9456 & $\begin{array}{l}\text { James M. Poterba } \\
\text { Scott Weisbenner }\end{array}$ & Inter-Asset Differences in Effective Estate Tax Burdens & $1 / 03$ \\
\hline 9457 & $\begin{array}{l}\text { Gerardo della Paolera } \\
\text { Alan M. Taylor }\end{array}$ & Gauch Banking Redux & $1 / 03$ \\
\hline 9458 & $\begin{array}{l}\text { Michael W. Brandt } \\
\text { Amir Yaron }\end{array}$ & $\begin{array}{l}\text { Time-Consistent No-Arbitrage Models of the } \\
\text { Term Structure }\end{array}$ & $1 / 03$ \\
\hline 9459 & $\begin{array}{l}\text { Jean Boivin } \\
\text { Marc Giannoni }\end{array}$ & Has Monetary Policy Become More Effective? & $1 / 03$ \\
\hline 9460 & Amy Finklelstein & $\begin{array}{l}\text { Health Policy and Technological Change: } \\
\text { Evidence from the Vaccine }\end{array}$ & $1 / 03$ \\
\hline 9461 & $\begin{array}{l}\text { Bruce N. Lehmann } \\
\text { David M. Modest }\end{array}$ & $\begin{array}{l}\text { Diversification and the Optimal Construction of } \\
\text { Basis Portfolios }\end{array}$ & $1 / 03$ \\
\hline 9462 & $\begin{array}{l}\text { Todd Sinai } \\
\text { Nicholas Souleles }\end{array}$ & Owner-Occupied Housing as a Hedge Against Rent Risk & < $1 / 03$ \\
\hline 9463 & $\begin{array}{l}\text { Michael R. Darby } \\
\text { Lynne G. Zucker } \\
\text { Andrew Wang }\end{array}$ & $\begin{array}{l}\text { Universities, Joint Ventures, and Success in the } \\
\text { Advanced Technology Program }\end{array}$ & $1 / 03$ \\
\hline 9464 & $\begin{array}{l}\text { Stephen J. Brown } \\
\text { William N. Goetzmann } \\
\text { Bing Liang }\end{array}$ & Fees on Fees in Funds of Funds & $1 / 03$ \\
\hline 9465 & $\begin{array}{l}\text { William N. Goetmann } \\
\text { Ning Zhu }\end{array}$ & Rain or Shine: Where is the Weather Effect? & $1 / 03$ \\
\hline 9466 & $\begin{array}{l}\text { William N. Goetzmann } \\
\text { Ning Zhu }\end{array}$ & $\begin{array}{l}\text { Efficiency and the Bear: Short Sales and Markets } \\
\text { around the World }\end{array}$ & $1 / 03$ \\
\hline
\end{tabular}


To order any of these papers in hard copy, see instructions at the end of this list. To subscribe to all NBER Working Papers or the papers in a single area, see instructions inside the back cover.

\begin{tabular}{|c|c|}
\hline Number & Author(s) \\
\hline 9467 & $\begin{array}{l}\text { C. Nicholas McKinney } \\
\text { Muriel Niederle } \\
\text { Alvin E. Roth }\end{array}$ \\
\hline 9468 & Christopher J. Ruhm \\
\hline 9469 & $\begin{array}{l}\text { William N. Goetzmann } \\
\text { Matthew Spiegel } \\
\text { Andrey Ukhov }\end{array}$ \\
\hline 9470 & $\begin{array}{l}\text { Stephen J. Brown } \\
\text { William N. Goetzmann } \\
\text { Takato Hiraki } \\
\text { Noriyoshi Shirishi } \\
\text { Masahiro Watanabe }\end{array}$ \\
\hline 9471 & $\begin{array}{l}\text { Martin Gaynor } \\
\text { William B. Vogt }\end{array}$ \\
\hline 9472 & Jeffrey Grogger \\
\hline 9473 & $\begin{array}{l}\text { David Card } \\
\text { Thomas Lemieux } \\
\text { W. Craig Riddell }\end{array}$ \\
\hline 9474 & Lance Lochner \\
\hline 9475 & Steven R. Grenadier \\
\hline 9476 & Amitabh Chandra \\
\hline 9477 & $\begin{array}{l}\text { Roger Gordon } \\
\text { Laura Kalambokidis } \\
\text { Joel Slemrod }\end{array}$ \\
\hline 9478 & $\begin{array}{l}\text { Raghuram Rajan } \\
\text { Luigi Zingales }\end{array}$ \\
\hline 9479 & $\begin{array}{l}\text { Graciela Kaminsky } \\
\text { Carmen Reinhart }\end{array}$ \\
\hline 9480 & $\begin{array}{l}\text { Li Gan } \\
\text { Michael Hurd } \\
\text { Daniel McFadden }\end{array}$ \\
\hline 9481 & $\begin{array}{l}\text { Rodolfo Martell } \\
\text { René M. Stulz }\end{array}$ \\
\hline
\end{tabular}

$\underline{\text { Title }}$

$\underline{\text { Date }}$

The collapse of a medical clearinghouse

(and why such failures are rare)

Healthy Living in Hard Times $\quad$ 1/03

Modeling and Measuring Russian Corporate 1/03

Governance: The Case of Russian Preferred

and Common Shares

Investor Sentiment in Japanese and U.S. Daily

$1 / 03$

Mutual Fund Flows

Competition Among Hospitals

$1 / 03$

Welfare Transitions in the 1990s: The Economy,

Welfare Policy, and the EITC

$1 / 03$

Unionization and Wage Inequality: A Comparative

Study of the U.S., the U.K., and Canada

Individual Perceptions of the Criminal Justice System 1/03

An Equilibrium Analysis of Real Estate 1/03

Is the Convergence in the Racial Wage Gap Illusory? 1/03

Do We Now Collect and Revenue from Taxing Capital 1/03

Income?

The Emergence of Strong Property Rights:

$1 / 03$

Speculations from History

The Center and the Periphery: The Globalization

$1 / 03$

of Financial Turmoil

Individual Subjective Survival Curves

$1 / 03$

Equity Market Liberalizations as Country IPOs

$2 / 03$ 
To order any of these papers in hard copy, see instructions at the end of this list. To subscribe to all NBER Working Papers or the papers in a single area, see instructions inside the back cover.

\begin{tabular}{|c|c|c|c|}
\hline Number & $\underline{\text { Author(s) }}$ & $\underline{\text { Title }}$ & $\underline{\text { Date }}$ \\
\hline 9482 & $\begin{array}{l}\text { Christopher Avery } \\
\text { Caroline M. Hoxby }\end{array}$ & $\begin{array}{l}\text { Do and Should Financial Aid Packages } \\
\text { Affects Students' College Choices }\end{array}$ & $2 / 03$ \\
\hline 9483 & Steven Shavell & Economic Analysis of Accident Law & $2 / 03$ \\
\hline 9484 & $\begin{array}{l}\text { Hiroshi Ono } \\
\text { Marcus E. Rebick }\end{array}$ & $\begin{array}{l}\text { Constraints on the Level and Efficient } \\
\text { Use of Labor in Japan }\end{array}$ & $2 / 03$ \\
\hline 9485 & $\begin{array}{l}\text { Edgar Cudmore } \\
\text { John Whalley }\end{array}$ & Border Delays and Trade Liberalization & $2 / 03$ \\
\hline 9486 & Lars E. O. Svensson & Monetary Policy and Real Stabilization & $2 / 03$ \\
\hline 9487 & $\begin{array}{l}\text { W. Kip Viscusi } \\
\text { Joseph E. Aldy }\end{array}$ & $\begin{array}{l}\text { The Value of a Statistical Life: A Critical } \\
\text { Review of Market Estimates throughout the World }\end{array}$ & $2 / 03$ \\
\hline 9488 & Peter Blair Henry & $\begin{array}{l}\text { Capital Account Liberalization, The Cost of } \\
\text { Capital, and Economic Growth }\end{array}$ & $2 / 03$ \\
\hline 9489 & $\begin{array}{l}\text { Magnus Blomstrom } \\
\text { Ari Kokko }\end{array}$ & The Economics of Foreign Direct Investment Incentives & $2 / 03$ \\
\hline 9490 & Jeffrey D. Sachs & $\begin{array}{l}\text { Institutions Don't Rule: Direct Effects of } \\
\text { Geography on Per Capita Income }\end{array}$ & $2 / 03$ \\
\hline 9491 & $\begin{array}{l}\text { Laurence Ball } \\
\text { N. Gregory Mankiw } \\
\text { Ricardo Reis }\end{array}$ & Monetary Policy for Inattentive Economies & $2 / 03$ \\
\hline 9492 & $\begin{array}{l}\text { Shinichi Nishiyama } \\
\text { Kent Smetters }\end{array}$ & $\begin{array}{l}\text { Consumption Taxes and Economic Efficiency } \\
\text { in a Stochastic OLG Economy }\end{array}$ & $2 / 03$ \\
\hline 9493 & Andrei Shleifer & Will the Sovereign Debt Market Survive? & $2 / 03$ \\
\hline 9494 & $\begin{array}{l}\text { Raphael Desmet } \\
\text { Alain Jousten } \\
\text { Sergio Perelman } \\
\text { Pierre Pestieau }\end{array}$ & $\begin{array}{l}\text { Micro-Stimulation of Social Security } \\
\text { Reforms in Belgium }\end{array}$ & $2 / 03$ \\
\hline
\end{tabular}

Copies of the above working papers can be obtained for $\$ 10.00$ per copy (plus $\$ 10.00$ per order for shipping for all locations outside the continental U.S.) to Working Papers, NBER, 1050 Massachusetts Avenue, Cambridge, MA 021385398. Pre-payment is required on all orders and may be made by check or credit card. Checks should be made payable to the NBER and must be in dollars drawn on a U.S. bank. If paying by credit card, include the cardholder's name, account number, and expiration date. For all orders, please be sure to include your return address and telephone number. Working papers may also be ordered by telephone (868-3900), fax (617-868-2742), or email (orders@nber.org). 